$\mathbb{T}$ periodica polytechnica

\author{
Civil Engineering \\ $56 / 2$ (2012) $233+238$ \\ doi: 10.3311/pp.ci.2012-2.09 \\ web: http://www.pp.bme.hu/ci \\ (c) Periodica Polytechnica 2012
}

RESEARCH ARTICLE

\section{Investigation of piping material}

\author{
László Nagy / Tamás Huszák
}

Received 2011-07-07, accepted 2012-04-16

\section{Abstract}

The grain size distribution of the material washed out from the piping under flood load, newer investigated earlier. Using 20 samples originating from different places at Danube and Tisza rivers, the grading characteristics of these samples were investigated on the basis of some selected grain sizes and the uniformity gradients. Based on these investigations it has become possible to identify which grain size fractions are likely to be washed out, and to characterise those fractions whose washing out is not expected. Based on the grain size distribution curves it has been made possible to define the boundaries of the zone susceptible to piping.

The zone limits of granular soils liquefied by earth quakes and the zone limits of the soil outwashed from piping are very similar. This apparent correspondence already formerly raised the hypothetic question of whether piping occurring during high flood can be simulated by shape to similar surface liquefaction phenomena experienced during earth quakes, as in both cases a volcanic cone is formed through the crater of which water is constantly issuing, dragging away solid particles. Recently the apparent similarity of the zones of grain size distribution curves in the two cases strongly suggest that the two phenomena should indeed be closely related.

\section{Keywords}

grain size distribution $\cdot$ sand boil $\cdot$ coefficient of uniformity . hydraulic soil failure

\section{László Nagy}

Department of Geotechnics, Budapest University of Technology, Múegyetem rkp. 3. Budapest, H-1521, Hungary

e-mail: lacinagy@mail.bme.hu

\section{Tamás Huszák}

Department of Geotechnics, Budapest University of Technology, Múegyetem rkp. 3. Budapest, H-1521, Hungary

e-mail: huszak@mail.bme.hu

\section{Introduction}

This paper places particular emphasis on a special feature in the protection against piping directing attention to some important aspects of flood defence and to the need for going into a deeper study of certain details of the phenomenon of piping. Undoubtedly, we know a great deal more about piping than we did just 30 years ago, nevertheless investigations need be continued [16. 17]. Research has been pursued in various fields in an attempt to find answers to some peculiar but very real problems, as follows:

- In the case of recorded actual pipings the mean hydraulic gradient only reached a value that was as low as less than one fifth of the allowable value, yet failure conditions did occur [8]. Sometimes the observed average hydraulic gradient was less than $0,1[1]$.

- Grading entropy shed light on soils prone to piping from the theoretical side $[2,5]$, but the practical approach revealed that in the vicinity of all the pipings a particular layer prone to piping failure invariably occurred in the stratified soil [6,7].

- The giant piping at Tiszasas (Fig. 1) in year 2000 raised a number of questions since piping occurred in the embankment (and not in the subsoil). This phenomenon formerly not heard of is quite possible provided that the material of the embankment is sufficiently loose and the fill contains a layer prone to piping.

- Parallel to what was mentioned above a remarkable development can be observed in international experience, in numerical modelling and in the study of transient phenomena of discrete particles to provide theoretical backing for flood phenomena.

Formerly little attention was paid to the investigation of material washed out of a piping [15]. The grain size distribution of the washed out material was not tested, nor was it compared to the grading of surrounding soil layers. Now, an important question arises: Is it the entire mass of a soil layer or only certain fractions of the soil that are washed out? During the high flood 


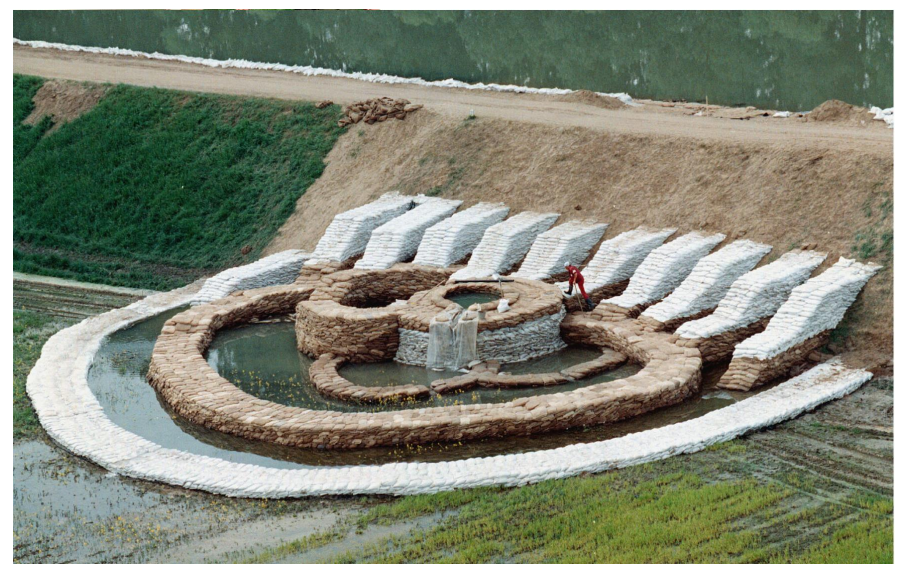

Fig. 1. The giant piping at Tiszasas in year 2000

on Danube in 2006, samples were taken from a number of pipings. Tests on these samples form the backbone of the present paper.

\section{Investigation of the sites}

The summary of investigated sites grouped according to the rivers and to the years of occurrence is contained in Table 1 Materials obtained from 12 pipings by river Tisza, 7 by Danube and 1 by river Sajó were tested. Based on these samples the effect of a number of factors has also been revealed at the various sites.

Whether grading curves of samples taken from pipings maximum a few metres away from each other show a different curve? Pipings located close nearby (samples $5-8$ and $17-18$ in Table 11) are supposed to give identical grading curves, yet testing experience indicates a difference in the shape of the grain size distribution curves (Fig. 2).

Another question also arises as to what differences if any can be between the grain size diagrams of two samples taken from different parts of the same piping (Samples No. 2-3, 5-6, 1415 and 19-20 respectively in Table 11. It can be stated that a difference does exist. Finer particles are conveyed and then deposited by the water farther away radially from the piping. Therefore at the central part where water is issuing in a concentrated flow sedimentation of the coarsest grains is expected, while finer grains settle at gradually increasing distances. As can be seen in Fig. 3, the difference between the grading curves can be relatively great.

It is a common premiss that any test is worth as much as the reliability of the underlying data. In Geotechnics, determination of the grain size distribution is a routine test and as such can be relied upon for correctness of test results. Yet, any theoretical conclusion is of no use if the determination of the grain size distribution curve is unreliable. The laboratory tests referred to in this set of tests were carried out at different laboratories, though the majority of the samples was tested at the Geotechnical Laboratory of the Budapest University of Technology

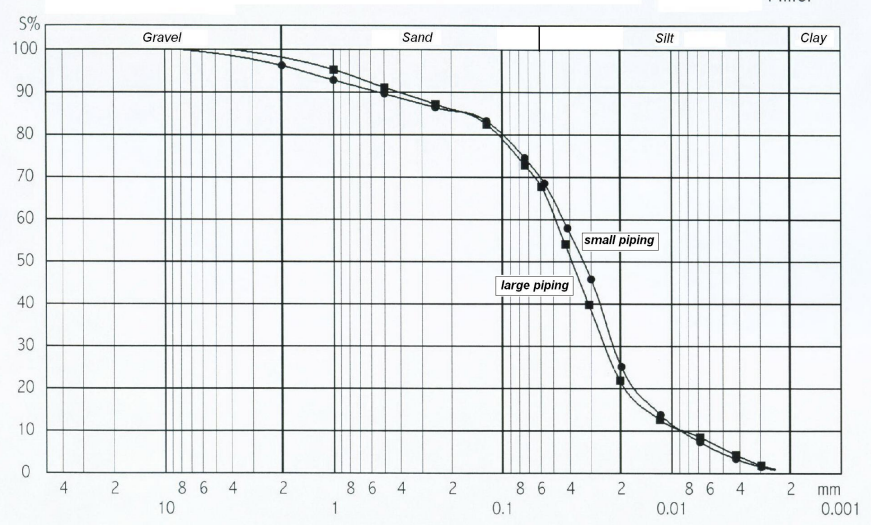

Fig. 2. Grain size distribution of two pipings located close to each other (Soils No. 17-18 in Tables 1 and2)

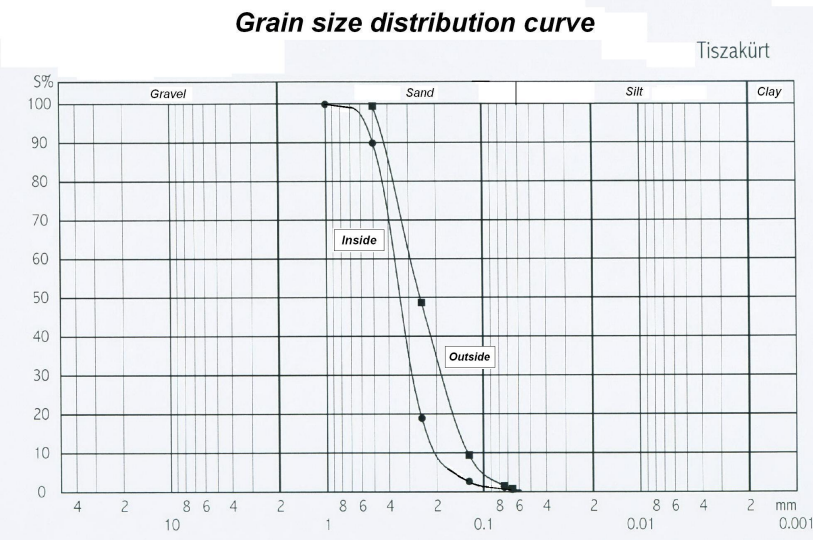

Fig. 3. Grain size distribution curves of two samples taken from different parts of the same piping (Soils No. 19-20 in Tables 1 and 2)

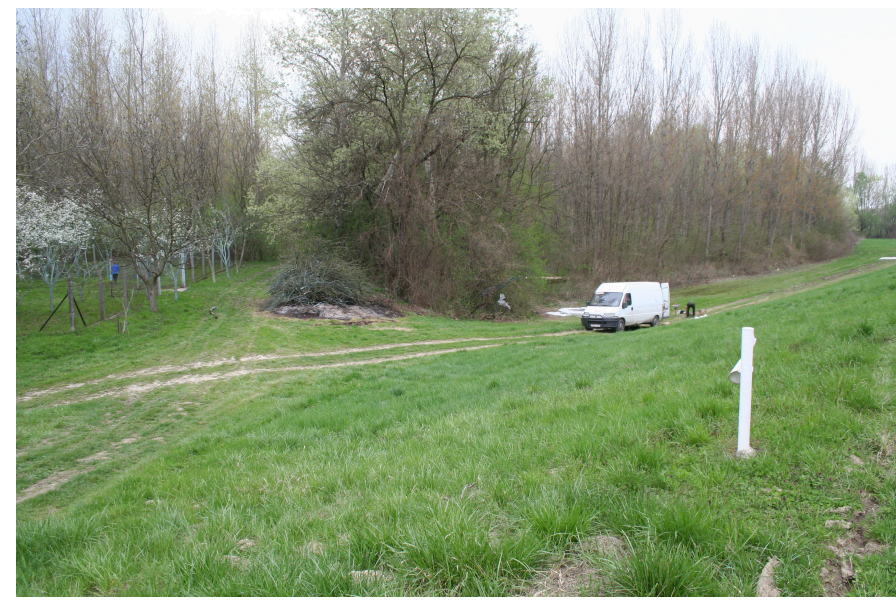

Fig. 4. Piping (partly behind the car) at the edge of an ox-bow near Bölcske (2006), with a difference in elevation of minimum two metres between ground level at the ox-bow and ground level at the adjacent high bank (Areas No. $9-$ 10 in Tables 1 and 2)

\section{Shape of the grain size distribution curve}

The grain size distribution curves of the material ejected from pipings have continuous smooth shape characteristic of natural soils. When the grain size distribution curves of all the samples tested are plotted in the same graph they clearly define a distinct zone. The types of soil located within this zone (silty sand, silty fine sand, fine sand, sand) exhibit no considerable cohesion, and 
Tab. 1. Sites of piping investigations

\begin{tabular}{|c|c|c|c|c|}
\hline Number & Year & River, location & Remarks & References \\
\hline 1 & 1998 & Tisza, right bank & Tivadar, inner side & 1113 \\
\hline 2 & 1998 & Tisza, right bank & Tivadar, outer side & 1113 \\
\hline 3 & 1998 & Tisza, right bank & Dombrád & 10 \\
\hline 4 & 2006 & Duna, right bank $12+150$ & Abda & \\
\hline 5 & 2006 & Duna, right bank. $41+206$ & Dombor, small piping & \\
\hline 6 & 2006 & Duna, right bank $41+206$ & Dombor, small piping, crater & \\
\hline 7 & 2006 & Duna, right bank $41+206$ & Dombor, big piping & \\
\hline 8 & 2006 & Duna, right bank $41+206$ & Dombor, big piping, crater & \\
\hline 9 & 2006 & Duna, right bank $79+420$ & Bölcske, ox-bow & \\
\hline 10 & 2006 & Duna, right bank $79+420$ & Bölcske, ox-bow & \\
\hline 11 & 2006 & Tisza, right bank $61+075$ & & \\
\hline 12 & 2006 & Tisza, right bank $71+300$ & & \\
\hline 13 & 2006 & Tisza, left bank $13+250$ & Tiszasas, marshy bushland & \\
\hline 14 & 2006 & Tisza, left bank $13+580$ & Tiszasas, edge of crater & \\
\hline 15 & 2006 & Tisz, left bank 13+580 & Tiszasas, centre of crater & \\
\hline 16 & 2010 & Sajó, left bank 6+266 & & \\
\hline 17 & 2010 & Tisza, Millér & Small piping & \\
\hline 18 & 2010 & Tisza, Millér & Large piping & \\
\hline 19 & 2010 & Tisza, Tiszakürt & Outer part of crater & \\
\hline 20 & 2010 & Tisza, Tiszakürt & Inner part of crater & \\
\hline
\end{tabular}

at the same time the mass of their individual soil particles is small enough allowing them to be readily removed from their position by seeping water (Fig. 6). It should be noted that under sufficiently high hydraulic gradients any type of soil (or even rock) can be washed out by piping. What is significant in this respect is that for soils within the domain in Fig. 6 the lowest hydraulic gradient is necessary.

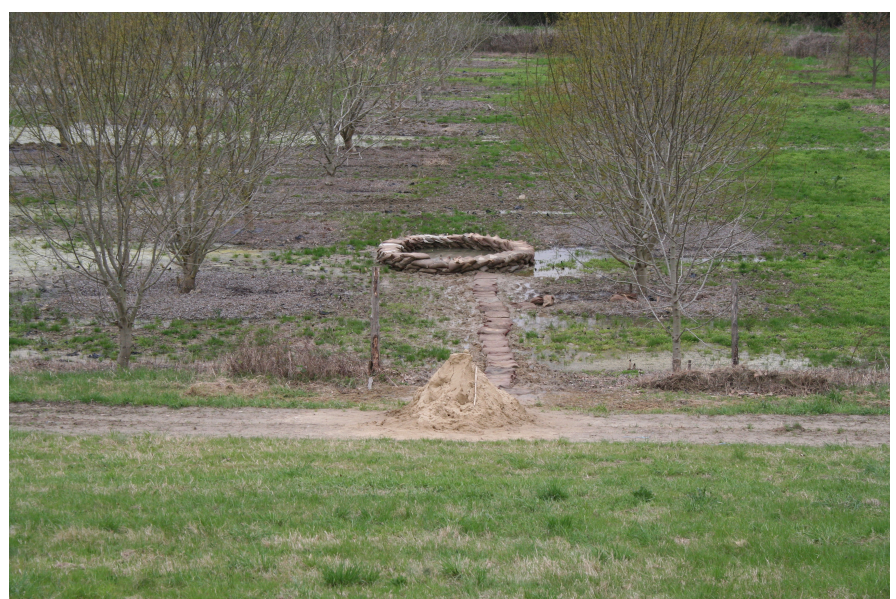

Fig. 5. Piping at Dombori as seen from the crest of the dyke. Washing out of soil first occurred some 20 metres away from the toe of the embankment (Areas No. 5-8 in Tables 1 and 2 )

The zone of grain size distribution curves of all the soils tested is shown again in Fig. 7. This zone shows a striking similarity to the zone representing the limits of granular soils liquefied by earth quakes. The grading limits shown in Fig. 3 are copied onto a graph presented in Smoltczyk's book [19] defining various degrees of hazard for liquefaction due to earth quake. (Zone 1: moderately susceptible, Zone 2: highly susceptible). This apparent correspondence already formerly raised the hypothetic question of whether piping occurring during high flood can be simulated by shape to similar surface liquefaction phenomena experienced during earth quakes, as in both cases a volcanic cone is formed through the crater of which water is constantly issuing, dragging away solid particles. The apparent similarity of the zones of grain size distribution curves in the two cases (Fig.5) strongly suggest that the two phenomena should indeed be closely related.

Following this reasoning one cannot help raising a question concerning the similarity of surface phenomena observed in both cases and the similarity of grading: i.e. whether piping constitutes a pseudo-static liquefaction or liquefaction (e.g. one triggered off by earth quake) constitutes a dynamic piping.

It should be noted that several expert's reports have recently been prepared dealing with failure of tailing dams where breach of the dam was judged to have been caused by liquefaction but in none of those cases was failure attributable to earthquake effect. This means that liquefaction may also occur under static loading conditions.

\section{The grain size pertaining to 10 percent passing}

In the study of the grain size distribution a crucial point is the determination of the grain size pertaining to 10 percent passing (See Table 2,). This grain size is determinant in respect of seepage phenomena and also in assessing the uniformity of grading. As can be seen in Fig. 8, in none of the tests on material washed out of the pipings were grain sizes $d_{10}>0,33$ or $d_{10}<0,0033$ identified. This means that a domain of grain sizes $d_{10}$ spanning over two orders of magnitude is affected in respect of washing out by piping. Frequency values should normally decrease towards both sides of the histogram but probably because of the 


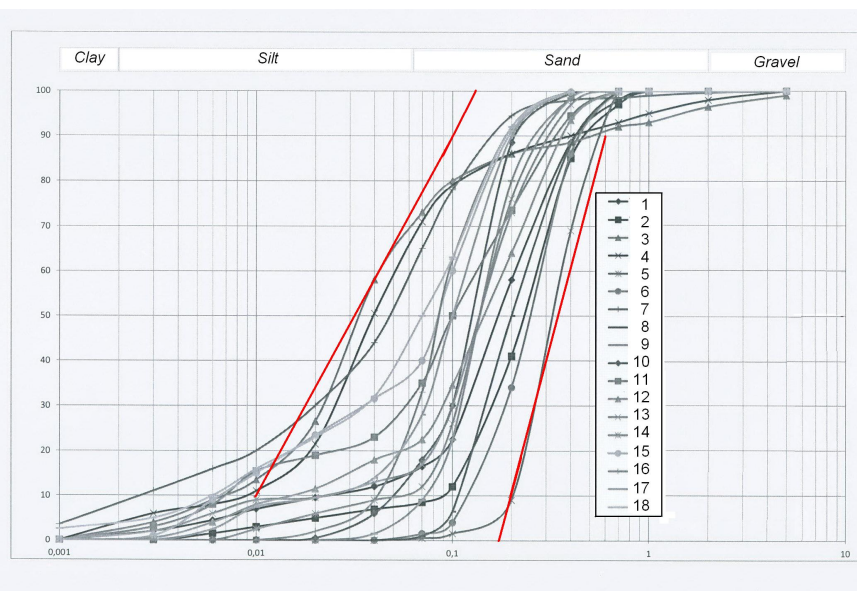

Fig. 6. Grain size distribution curves and limiting envelops of the critical zone

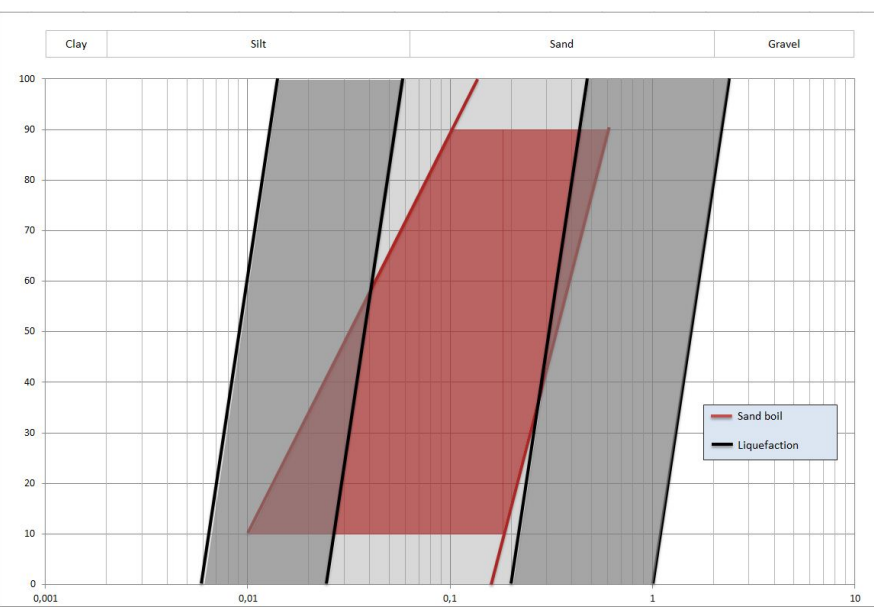

Fig. 7. Zones of soils most susceptible to liquefaction (Smoltczyk, 2002) with limiting lines for the zone of piping added

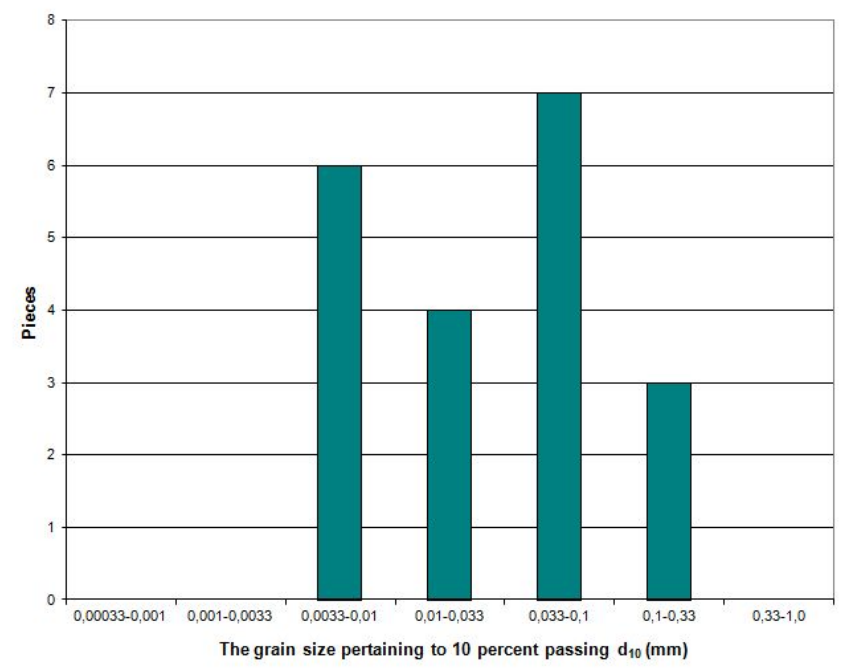

Fig. 8. Frequency distribution of $d_{10}$ values in the material washed out by piping

relatively small number of elements and the few number of categories this tendency does not appear here.
Tab. 2. Some characteristics of the material washed out by piping

\begin{tabular}{cccc}
\hline Number & $d_{10}$ & Uniformity coefficient $\left(C_{U}\right)$ & Description of soil \\
\hline 1 & 0,08 & 3,25 & Fine sand \\
\hline 2 & 0,025 & 8,4 & Silty sand \\
\hline 3 & 0,036 & 4,6 & Silty sand \\
\hline 4 & 0,0071 & 17,8 & Silty sand \\
\hline 5 & 0,007 & 13,9 & Silty sand \\
\hline 6 & 0,041 & 2,4 & Sand \\
\hline 7 & 0,026 & 4,3 & Sand \\
\hline 8 & 0,006 & 15,2 & Silty sand \\
\hline 9 & 0,026 & 6,5 & Silty sand \\
\hline 10 & 0,016 & 10,8 & Silty sand \\
\hline 11 & 0,056 & 2,1 & Fine sand \\
\hline 12 & 0,049 & 3,5 & Silty sand \\
\hline 13 & 0,106 & 2,2 & Fine sand \\
\hline 14 & 0,073 & 2,3 & Fine sand \\
\hline 15 & 0,051 & 2,6 & Fine sand \\
\hline 16 & 0,007 & 12,6 & Silty sand \\
\hline 17 & 0,007 & 6,1 & Silty sand \\
\hline 18 & 0,0083 & 5,9 & Silty sand \\
\hline 19 & 0,17 & 2,2 & Sand \\
\hline 20 & 0,13 & 2,3 & Sand \\
\hline & & &
\end{tabular}

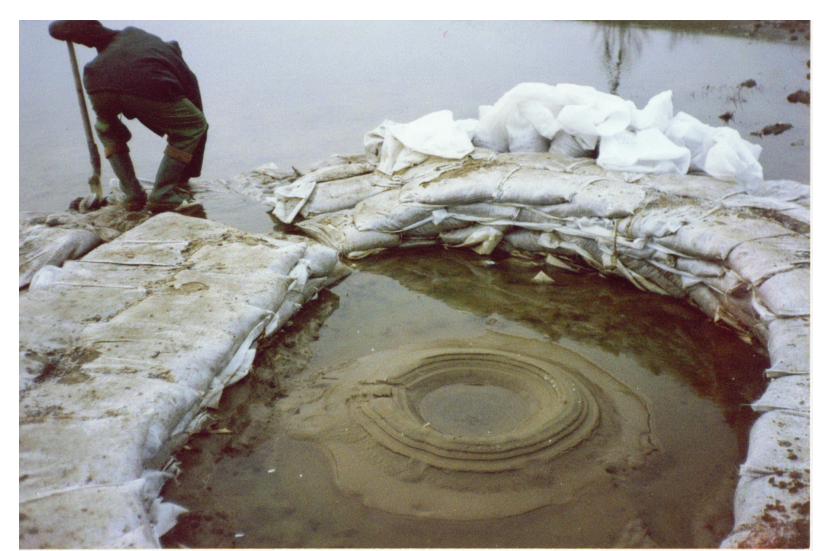

Fig. 9. Piping at Dombrád (1998), some $20 \mathrm{~m}$ away from the dyke toe (Area No. 3 in Tables 1 and 2)

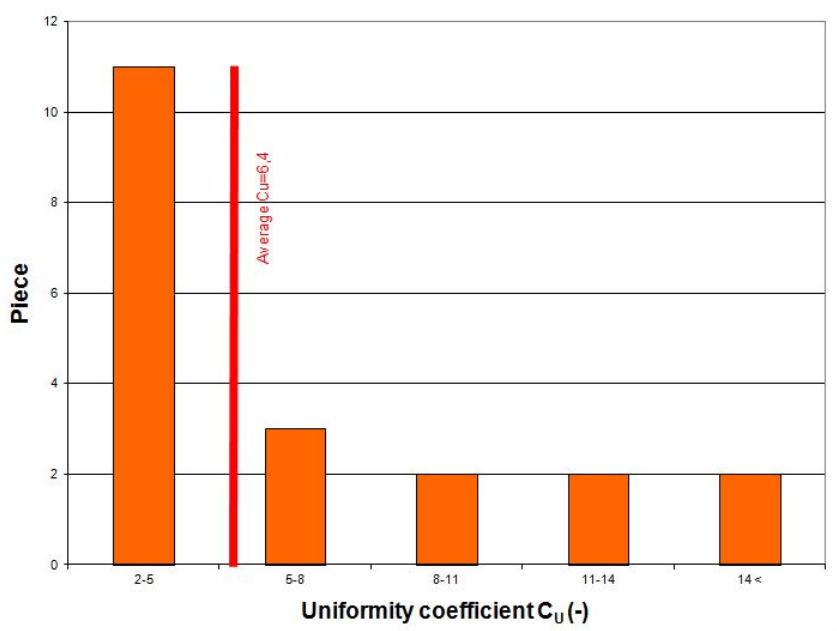

Fig. 10. Frequency distribution of uniformity coefficients in the material washed out by piping 


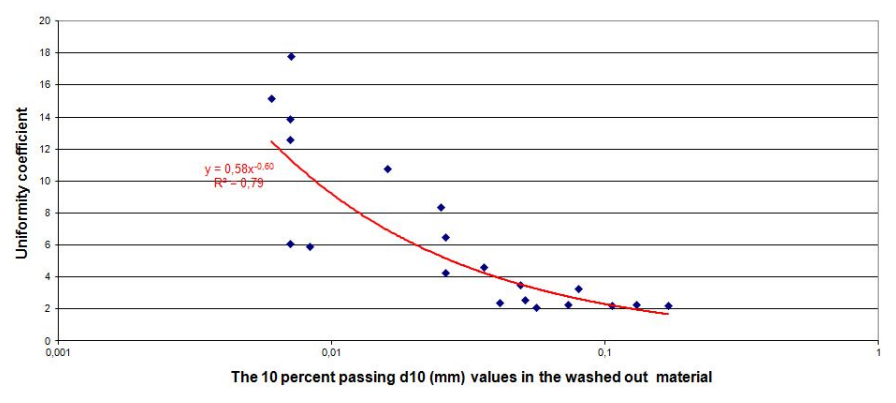

Fig. 11. The relationship between the uniformity coefficient and the grain size pertaining to 10 percent by weight passing

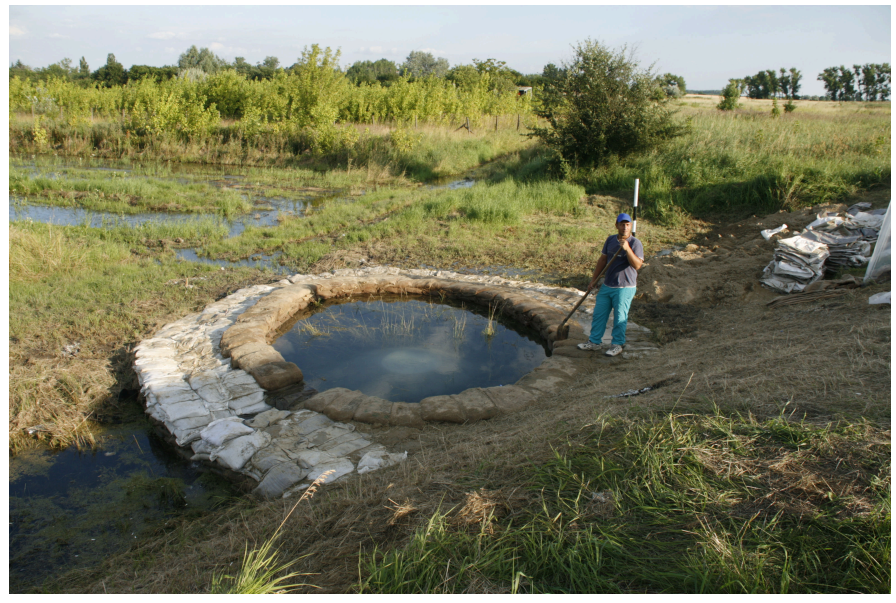

Fig. 12. Piping at the initial section of a trench drain near Tiszakürt in 2010 (Areas No. $19-20$ in Tables 1 and 2)

\section{The uniformity coefficient}

Uniformity coefficient $\left(C_{U}\right)$ values of the washed out soils are shown in Table 2 The highest value was $C_{U}=17,8$, and the mean value was $C_{U}=6,4$. No soil with $C_{U}<2,0$ was identified. The frequency distribution of the uniformity coefficients can be seen in Fig. 10, where the category of $C_{U}=2-5$ is the most populous, containing more than half of the samples tested. Fine grained soils with low coefficient of uniformity are the ones that can be most readily washed out or removed from their position, since they have no cohesion and the mass of their grains is small.

\section{Correlation between uniformity coefficient and grain size $d_{10}$}

An evaluation of the relationship between the uniformity coefficient $\left(C_{U}\right)$ and the grain size pertaining to 10 percent by weight passing leads to an inverse relation, that is the value of $C_{U}$ tends to decrease with the increase in $d_{10}$. In other words: the more coarse- grained the washed out soils, the more closely they are to a perfectly uniform single-grained soil. The most astonishing fact is the very tight correlation giving a value of nearly $R=0,9$ !! (See Fig. 11), in spite of the fact that the samples originated from various regions of the country and were tested in several laboratories.

\section{Conclusion}

Pipings are the most spectacular phenomena preceding and ultimately leading to breach of flood protection dykes. A re- view of historic data showed that 1 in every 12 to 13 embankment failures was the consequence of piping [10]. Flood defence counter measures to conquer pipings are well established and proven, [9, 13, 16, 18, 20, 21], while theoretical treatment of ground failure due to piping is not satisfactorily profound. It is an undisputable fact that we know a great deal more about piping than we did say 30 years ago, but continued research must go on even by resorting to practical experience if necessary. Neither hydraulic criteria, nor structural criteria of piping are known deeply enough. We are surely aware of certain parameters that contribute to the build-up of pipings, but their effect cannot yet be quantified. In the case of fully developed pipings the average hydraulic gradient normally has a value hardly reaching one fifth of the allowable threshold value, yet ground failure does occur. Density conditions have not been properly dealt with, and also little attention has been paid to the testing of material ejected by piping.

This paper looks at the process of piping from the aspect of material structure by focussing on the grain size distribution of the material washed out from the piping. Using 20 samples originating from different regions of Hungary, the grading characteristics of these samples were investigated on the basis of some selected grain sizes and the uniformity gradients. Based on these investigations it has become possible to identify which grain size fractions are likely to be washed out, and to characterise those fractions whose washing out is not expected. Based on the grain size distribution curves it has been made possible to define the boundaries of the zone susceptible to piping. The investigations provided useful results concerning values of the uniformity gradient and the grain size pertaining to 10 per cent and the relationship between them.

In order to obtain a deeper understanding of the process of piping the question whether the washed out material consists of the entire mass of a layer or only of a grain size fraction within the layer needs be investigated. To this end a more profound knowledge of the environment of the piping would be very important.

\section{References}

1 Brandl H, Geosynthetics Applications for the Mitigation of Natural Disasters, 9th International Conference on Geosynthetics (IGS) (Guaruja/Sao Paulo - Brazil, Conf. Proceedings, 2010), pp. 215-231.

2 Imre E, Rózsa P, Lörincz J, Characterization of some sand mixtures, 12th Int. Con. of Int. Association for Computer Methods and Advances in Geomechanics (IACMAG) (Goa, India, 2008), pp. 2064-2075.

3 Lőrincz J, Soils grading entropy (Talajok szemeloszlási entrópiája), BME Civil engineering Faculty, Geotechnical Department, 1986.

4 Lörincz J, On particle migration with the help of grading entropy, Conf. on Filter sin Geotechnical and Hydraulic Engineering (Balkema, Rotterdam, The Netherlands, 1993), pp. 63-65.

5 Lörincz J, Imre E, Gálos M, Trang Q P, Telekes G, Rajkai K, Grading entropy variation due to soil crushing, Second International Conference from Experimental Evidence Towards Numerical Modelling of Unsaturated Soils (Bauhaus-university, Weimar, Germany, 2003), pp. 215-231.

6 Lörincz J, Nagy L, Practical characterization of piping with the help 
of grading entropy. (Buzgárosodásra való hajlam gyakorlati vizsgálata szemeloszlási entrópia segítségével), Hidrológiai Közlöny 90 (2010), no. 3, 59-64.

7 Lőrincz J, Nagy L, Árvízvédelmi töltések altalajának vizsgálata buzgárosodásra való hajlam szempontjából a szemeloszlási entrópia segítségével (Subsoil piping investigation of flood dikes with the help of grading entropy), 1995.

8 Nagy L, Zabó T, Fehér Á, Hrehuss G., Engineering Geophysical Method for Risk Mapping of Flood Protection Sub-catchment Defended by Levees, 7th Int. IAEG Congress (Lisboa, Portugal, 1994).

9 Nagy L, Szlávik L, Árvízvédekezés a gyakorlatban, (Flood control in the practice), KTVM Vízügyi Hivatala, Budapest, 2004.

10 Nagy L, Dike breaches in the Carpathian Basin, Periodica Polytechnica 50 (2004), no. 2, 115-124.

11 Nagy L, Investigation of the Dombrád piping. (A dombrádi buzgár vizsgálata.), Vízügyi Közlemények 1 (2003), 205-215.

12 Nagy L, The Tivadar piping. (A tivadari buzgár), 17. MHT Vándorgyúlés (Miskolc, 1999), pp. 130-146.

13 Nagy L, Flood control at the villages. (Árvízvédekezés a településeken.), Innova-Print Kft. nyomda, Budapest, 2011.

14 Nagy L, Investigation of the Tivadar piping at 1998. november flood. (Az 1998. novemberi tivadari buzgár vizsgálata.), Hidrológiai Közlöny 4 (1999), 217-222.

15 Nagy L, Geotechnical problems of dikes. (Az árvízvédelmi gátak geotechnikai problémái.), Vízügyi Közlemények 1 (2000), 121-146.

16 Nagy L, Hydraulic failure probability of a dike cross section, Periodica Polytechnica, Civil Engineering 52 (2008), no. 2, 83-89, DOI 10.3311/pp.ci.2008-2.04.

17 Péch J, Dike defense, Practical guideline for water engineers and flood control experts. (Gátvédelem, Gyakorlati kézikönyv vízi mérnökök és gátvédók részére.), 1892.

18 Polgár et al. (ed.), Flood defense handbook. (Árvízvédekezési kézikönyv)., VÍZDOK, 1974.

19 Smoltczyk U (ed.), Geotechnical Engineering Handbook, 2002.

20 Szlávik L, Nagy L, A surányi jelenség. Veszélyes töltés meghibásodások az 1997. évi júliusi dunai árhullám levonulásakor. (The Surány phenomenon. Dangerous dike failures during the 1997 year summer flood), Víztükör 4 (1997), 35.

21 Tápay L, Szalai M, Flood control handbook. (Árvízvédelmi kézikönyv), 1954. 